198 Paediatrica Indonesiana 15 : 198 - 206. July - August 1975.

From the Department of Child Health, Medical School

University of Indonesia, Jakarta, Indonesia

\title{
Effect of Low Lactose Milk "Eiwit Melk"(E.M.) on Low Birth Weight Infants with Diarrhoea
}

by

TB. BAGDADIJI. SUHARJONO. ASWITHA BOEDIARSO and SUNOTO

\begin{abstract}
Thirty-nine low birth weight infants suffering from diarrhoea hospitalized in the Department of Child Health, Dr. Tjipto Mangunkusumo Hospital/Medical School University of Indonesia from July 1972 to December 1973 were treated with "Eiwit Melk" (low lactose milk).

Results are not satisfactory although better than with the routine formula.

9 out of 39 cases (23\%) give excellent result.

3 out of 39 cases ( $7.6 \%)$ give good result.

27 out of 39 cases (69.4\%) give poor result.

In low birth weight infants, next to lactose intolerance, other factors in causing diarrhoea among others fat malabsorption should be considered.

Trials with formulas combining easity absorbable fats should be encouraged.
\end{abstract}

Feceived 6th. Dec. 1974 


\section{Introduction}

In low birth weight newborns, temporary milk intolerance for a few days could occur until their lactase reaches adequate levels to be able to digest the lactose in the formula (Bayless and Christopher, 1969).

The common carbohydrates in an infant's diet are the disaccharides lactose and sucrose, which are hym drolyzed to monosaccharides by the enzymes lactase and sucrase in the brush border of the small bowel mucosa (Holzel, 1957).

Auricchilo et al. in 1965 found that the glycosidase activities are present by the third month of intra uterime life, when the intestinal mucosa is already differentiated. All alfa dilsaccharidase activities (namely, those of the maltase and sucrase) reach a maximum during the sixth or seventh month of intra uterine life, whilst the bieta glucosidases (lactase) develop rapidly during antenatal existence and reach their peak at the end of normal gestation. So there will be a low concentration of lactase in low birth weight infants.

Small bowel biopsy from patients who fail to thrive after gastroenteritis often demonstrates histologically the presence of severe partial villous atrophy. This may persist for several months, but the mucosa usually returns to normal without specific therapy (Walker Smith, 1970).
The enzyme lactase is produced and acts in the brush border of the microvilli (Suharjono et al., 1974). Lactase deficiency in gastroenteritis due to changes in villous pattern might cause lactose intolerance.

This paper presents the results of our study and discusses the effects of low lactose milk on low birth weight (LBW) infants with diarrhoea.

\section{Material and Method}

Thirty-nine LBW infants age ranging from 4 to 40 days and body weight ranging from 1000 to 2450 grams with diarrhoea, who were hospitalized in the Department of Child Health, Medlical School, University of Indonesia in 1973, belonged to this study. They were treated with a low lactose milk Eiwit Melk" (E.M.), which contains 1.4\% lactose.

The main composition as a solution of 1 liter is as follows:

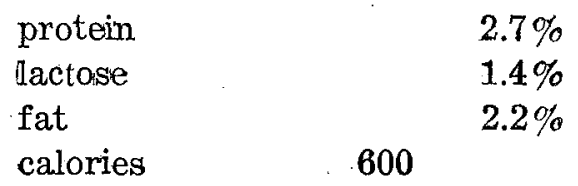

As a control was put $8 \mathrm{LBW}$ other infants of SGM (a locally produced formula) of which the main composition as a solution of 1 liter is as follows :

$\begin{array}{lr}\text { protein } & 2.4 \% \\ \text { lactose } & 3.1 \% \\ \text { fat } & 1.3 \% \\ \text { calories } & 514\end{array}$


TABLE 1 : Effects of Low Lactose Mill ("Eiwoit Melk") in Low Binth Weight infants with diarthoea

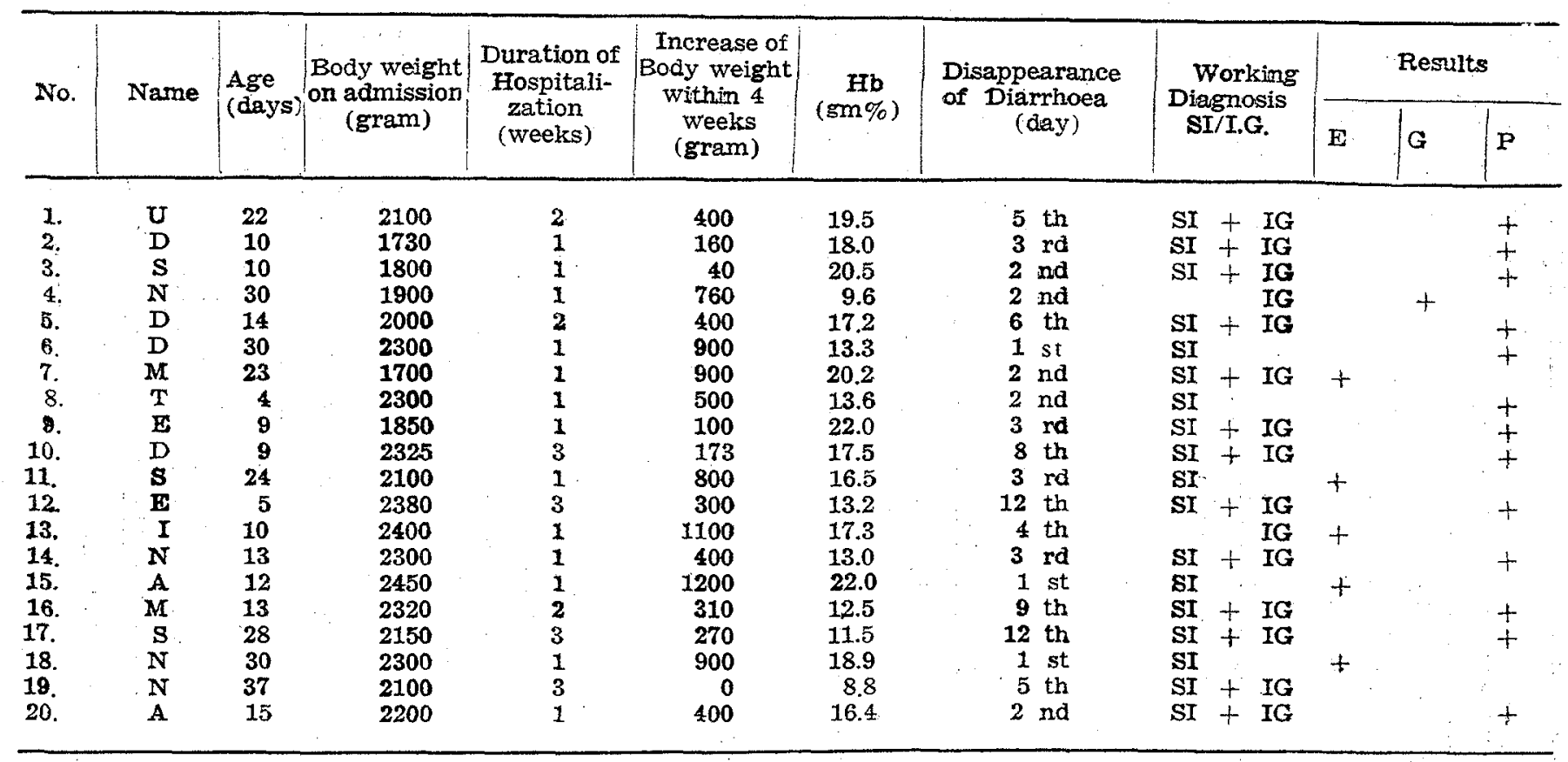

SI : Sugar Intolerance; IG : Infection of the Gut; $\mathbf{E}$ : Excellent; $\mathrm{G}$ : Good; $\mathbf{P}$ : Poor 
TABLE 1 (continued).

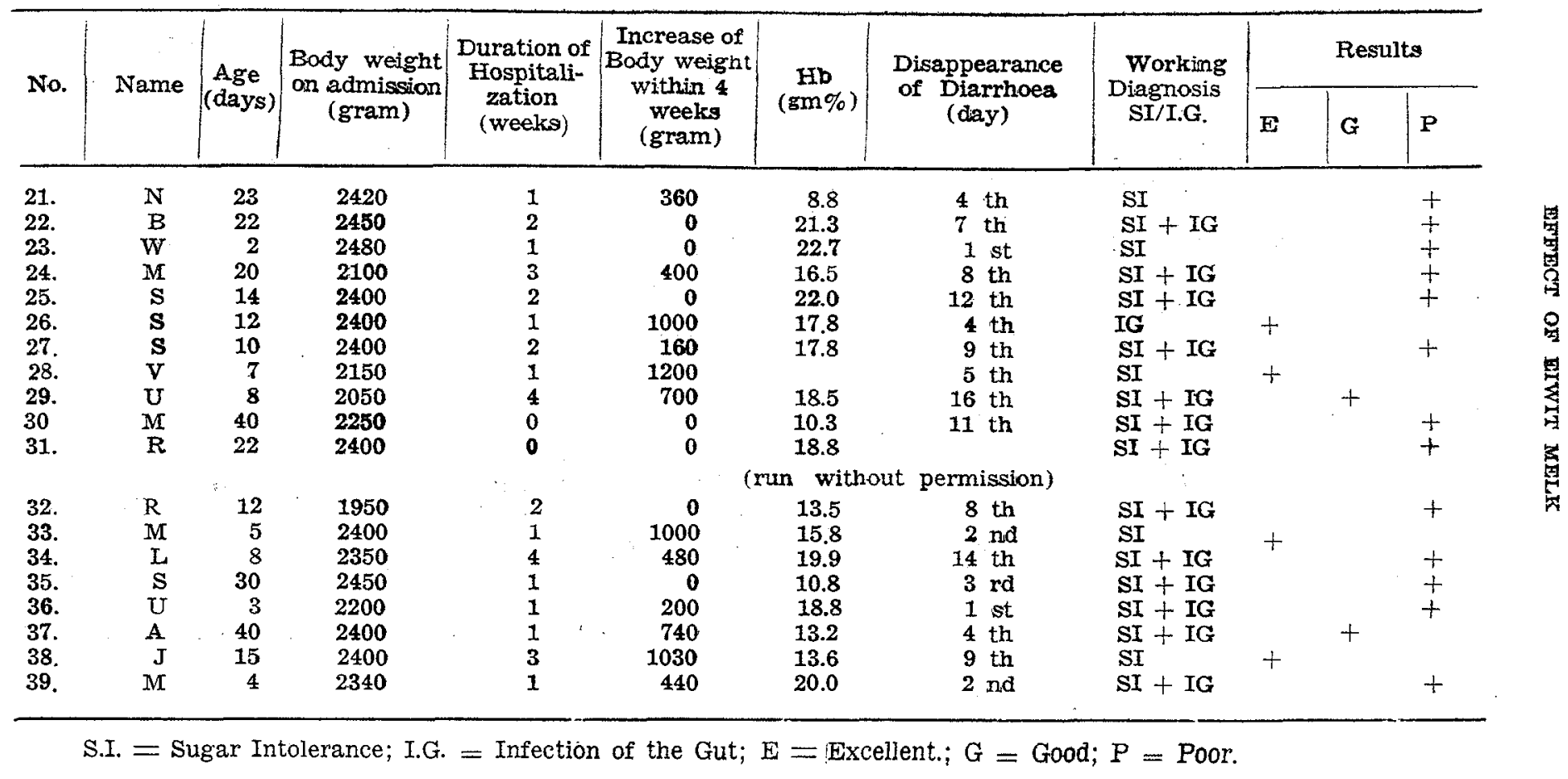


TABLE 2 : Effect of $S G M$ in $L B W$ infants with diarrhoea.

\begin{tabular}{|c|c|c|c|c|c|c|c|c|c|c|c|}
\hline \multirow{2}{*}{ No. } & \multirow{2}{*}{ Name } & \multirow{2}{*}{$\begin{array}{l}\text { Age } \\
\text { (days) }\end{array}$} & \multirow{2}{*}{$\begin{array}{c}\text { Body weight } \\
\text { on admission } \\
\text { (gram) }\end{array}$} & \multirow{2}{*}{$\begin{array}{c}\text { Duration of } \\
\text { Hospitali- } \\
\text { zation } \\
\text { (weeks) }\end{array}$} & \multirow{2}{*}{$\begin{array}{l}\text { Increase of } \\
\text { Body weight } \\
\text { within } 4 \\
\text { weeks } \\
\text { (gram) }\end{array}$} & \multirow{2}{*}{$\begin{array}{c}\mathrm{Hb} \\
(\mathrm{gm} \%)\end{array}$} & \multirow{2}{*}{$\begin{array}{l}\text { Disappearance } \\
\text { of Diarrhoea } \\
\text { (day) }\end{array}$} & \multirow{2}{*}{$\begin{array}{l}\text { Working } \\
\text { Diagnosis } \\
\text { SI/I.G. }\end{array}$} & \multicolumn{3}{|c|}{ Results } \\
\hline & & & & & & & & & $\mathrm{E}$ & $\mathbf{G}$ & $\mathrm{P}$ \\
\hline 1. & $\mathbf{S}$ & 31 & 2360 & 1 & 1160 & 8.6 & 4 th & IG & + & & \\
\hline 2. & $w$ & 24 & 2400 & 1 & 920 & & 3 th & IG & + & & + \\
\hline 3. & A & 11 & 2450 & 2 & 400 & 15.7 & 8 th & $\mathbf{S I}+\mathbf{I G}$ & & & \\
\hline 4. & $J$ & 15 & 2400 & 3 & 0 & 16.8 & 10 th & IG & & & \\
\hline 5. & $\mathrm{~N}$ & 13 & 2480 & 1 & 880 & 19.5 & 2 th & $I G$ & + & & + \\
\hline 6. & $\mathbf{S}$ & 6 & 1000 & 1 & 600 & 15.0 & 2 th & IG & + & & + \\
\hline 7. & $\mathrm{~J}$ & 15 & 1770 & 3 & 310 & 11.0 & 4 th & $\mathrm{SI}+\mathrm{IG}$ & & & + \\
\hline 8. & $w$ & 4 & 2000 & 1 & 400 & 14.8 & 5 th & $\mathrm{SI}+\mathrm{IG}$ & & & + \\
\hline
\end{tabular}

SI = Sugar intolerance; IG = Infection of the gut;

$\mathrm{E}=$ Excellent; $\mathrm{G}=$ Good;

$\mathrm{P}=$ Poor. 
TABLE 3 : Summary of the Trial on 39 LBW infants with diarrhoea refed with EM

\begin{tabular}{|c|c|c|c|c|c|c|c|}
\hline \multirow{2}{*}{ Age } & \multirow{2}{*}{$\begin{array}{l}\text { Number of } \\
\text { Subjects }\end{array}$} & \multicolumn{3}{|c|}{ Working diagmasis } & \multicolumn{3}{|c|}{ Results } \\
\hline & & SI & IG & $\mathrm{SI}+\mathrm{IG}$ & $\mathbf{E}$ & $G$ & $\mathbf{P}$ \\
\hline $0-15$ days & 23 & 7 & 1 & 15 & 6 & 1 & 16 \\
\hline $\begin{array}{r}15 \text { days - } \\
1 \text { manth }\end{array}$ & 16 & 1 & 1 & 11 & 3 & 2 & 11 \\
\hline Total & 39 & 11 & 2 & 26 & 9 & 3 & 27 \\
\hline
\end{tabular}

$\mathrm{E}=$ Excellent $\mathrm{G}=$ Good; $\mathrm{P}=$ Poor.

TABLE 4: Summary of the Trial on 8 LBW infants with diarrhoea refed with SGML

\begin{tabular}{|c|c|c|c|c|c|c|c|}
\hline \multirow{2}{*}{ Age } & \multirow{2}{*}{$\begin{array}{c}\text { Number of } \\
\text { Subjects }\end{array}$} & \multicolumn{3}{|c|}{ Working diagnosis } & \multicolumn{3}{|c|}{ Resuits } \\
\hline & & SI & IG & $\mathrm{SI}+\mathrm{IG}$ & $E$ & $G$ & $\mathbf{P}$ \\
\hline $0-15$ days & 4 & 1 & 1 & 2 & 1 & - & 3 \\
\hline $\begin{array}{l}15 \text { days } \\
1 \text { month }\end{array}$ & 4 & 2 & 1 & 1 & 2 & - & 2 \\
\hline Total & 8 & 3 & 2 & 3 & 3 & - & 5 \\
\hline
\end{tabular}

$\mathrm{E}=$ Excellent; $\mathrm{G}=$ Good; $\mathrm{P}=$ Poor. 
There were no other serious conditions except enteritis. One infant died because of worsening of the enteritis.

The nutritional status was evaluated weekly until approximately 4 weeks of hospitallization.

\section{Resulits}

The criteria of growth used are as follows :

Excellent, if the increase of body weight within 1 month ( 4 weeks) divided by the natural optimal increase reflected by body weight and age is more than one.

\section{Example :}

A 31-day-oldinfant with a body weight of 2.000 grams on admission was hospittalized during 4 weeks.

On dilscharge, the body weight was 3.000 grams. So the increase of body weight within one month (4 weeks) was 1.000 grams.

The natural optimal monthly increase of an infiant with a body weight of 2.000 grams as a healthy infant, of the first trimester of age is 750 grams.

Increase of body weight ( 1 month)

optimal increase ( 1 month)

$$
=\frac{1.000}{750}=>1
$$

The result in thire patient is considered excellent.
Good, if the ratio obtained according to the above mentioned calculation is approximately 1 .

Example:

A 30-day-old infant, with a body weight of 1.900 grams on admission, was hospitalized during 4 weeks.

On discharge, the body weight was 2.650 grams. So the increase of body weight within one month (4 weeks) is 650 grams.

The natural optimal monthly increase of an infant with a body weight of 1.900 grams as a healthy infant, of the first trimester of age is 750 grams.

Increase of body weight (1 month)

optimal increase (1 month)

$=-\frac{750}{750}=1$.

The result in this patient is considered good.

Poor, if the ratio is less than 1.

Example :

A 38-day-old infant, with a body weight of 2.340 grams on admission, was hospitalized during 4 weeks.

On discharge, the body weight was 2.740 grams. So the increase of body weight within one month (4 weeks) was 400 grams.

The natural optimal monthly intcrease of an infant with a body 
weight of 2.340 grams as a healthy infant, of the first trimester of age is 750 grams.

Increase of body weight ( 1 month)

optimal increase (1 month)

$=\frac{400}{750}=<1$

The result in thils patient is considered poor.

The result of this study can be seen in tables 1 and 2 .

Table 1 shows the effect of "Eiwit Melk" as follows :

excellent on 9 out if 39 patients $=$ $23.1 \%$

good on 3 out of 39 patients $=$ $7.6 \%$

excellent on 3 out of 8 patients $=$ $69.6 \%$

Table 2 shows the effect of SGM as follows :

excellent on 3 out of 8 patients $=$ $37.5 \%$

good on 0 out of 8 patients $=0 \%$ poor on 5 out of 8 patients $=62.5 \%$

\section{Discussion}

As it has been described earlier, there will be a low concentration of lactase in low birth weight infants. It is justifiable that we choose a low or free lactose milk for those low birth weight babies. Miller and Crane (1964) stated that disaccharidases are found within the brush border lining of the luminal surface of the initestinal epithelium, and therefore are liable to be effected in any disorder in which the intestinal mucosa is damaged.

Examples are gastroenteritis, protein calorie malnutrition and some parasiltic infestations.

Normally, lactase is present in lower concentration as compared with other brush border disaccharidases (Dahlquist, 1964); it is allso the last to recover completely following mucosial damage (Plotkin and Isselbacher, 1964). Compared to older infanits with diarrhoea, the incidence of fat malabsorption in low birth weight infants with diarrhoea is much higher due to possilbly persisting immature function of the organs e.g. liver, pancreas, intestine otc. next to the inadequate condition of the epithelial cells caused by the diarrhoea. From the study on 26 Indonesian infants with diarrhoea, $80.8 \%$ shows fat malabsorption (Gracey et al., 1974).

So, in treating diarrhoeal low birth wieight infants, besides low or lactose free formula milk containing easily absorbable fats should also be seriously considered. From the present study, it got only $23.1 \%$ excellentand $7.6 \%$ good results in treating those low binth weight infants with milk containing only low lactose (see table 1). 
TB. BAGDADIJI ET AL

The results of SGM to 8 other low birth weight infants were also poor for the majority (see table 2). This latter is not surprising since SGM contains more lactose than "Eiwit Melk".

In general, the conclusion drawn from this trial is that formulas with low lactose alone in low birth weight infants with diarrhoea will not give good results; other factors such as poor fait absorption due to persisting immaturity of the enzymes producing organs might play a similar important role.

\section{REEERENCES}

1. AURICCHIO, S., RUBINO, N. and MURSET, G. : Intestinal glucosidase activities in human embryo, fetus and newborn. Pediatr. 35 : 944 (1965).

2. BAYLESS, T.M. and CHRISTOPHER, N.L. : Disaccharidase deficiency. A.m. J. clin. Nutr. 22 ; 181 (1969).

3. DAHLQVIST, S.: Method for assay of Intestinal disaccharidases. Analyt. Biochem. $7: 18$ (1964).

4. GRACEY, M., THOMAS, J., SUHARJONO and HENTYANTO HENDARDJI : Assessment of steatorrhoea in malnourished children. Lipiodol absorption test. Environ. Child Hlth. 20:223 (1972).

5. HOLZEL, A. : Sugar malabsorption due to deficiencies of disaccharidase activities and of monosaccharide tran- sport. Arch. Dis. Chilah. 212 : 341 (1957).

6. MILLER, D, and CRANE, R.K.: The digestive function of the epithelium of the small intestine. Biochem. Biophys. Acta $52: 293$ (1961).

7. PLOTKIN, C.R. and ISSEL BACHER, K.J. : Secondary disaccharidase deficiency in malabsorption states. N. Engl. J.Med. 27 : 1033 (1964).

8. SUHADRJONO, I.G.N, WILA WIRYA, SAMSUDIN, SUNOTO, ZEIN SULAIMAN and SUTEDJO : Effect of low lactose milk on protein calorie malnutrition. Presentel at the First Asian Pediatric Congress, Manila, May 1974. Paediatr. Indones in prin .

9. WALKER SMITH, J.A.: Diseases of the small bowel in childhood. Postgrad. med. J. $46: 300$ (1970). 